\title{
Compact Pattern
}

National Cancer Institute

\section{Source}

National Cancer Institute. Compact Pattern. NCI Thesaurus. Code C35923.

Closely crowded or packed tog ether. 